Tyndale Bulletin 70.1 (2019) 95-115

\title{
THE COHERENCE OF PENAL SUBSTITUTION
}

\author{
AN EDWARDSEAN DEFENCE
}

\author{
Chris Woznicki \\ (christopherwoznicki@fuller.edu)
}

\begin{abstract}
Summary
Among recent evaluations of penal substitutionary atonement one significant critique is that given the necessary and sufficient conditions for punishment the doctrine is incoherent. In this essay I defend the coherence of penal substitution by providing an account of Christ's relationship to humanity such that it is conceptually possible to meet the necessary and sufficient conditions for punishment. In order to do this, I turn to Jonathan Edwards' understanding of creation and identity. I show that a view called 'Edwardsean Anti-Criterialism' provides the metaphysics necessary for a coherent account of penal substitution.
\end{abstract}

\section{Introduction}

Penal substitutionary atonement is a critical aspect of the gospel. Chapter VIII, article V of the Westminster Confession of Faith states:

The Lord Jesus, by his perfect obedience, and sacrifice of Himself, which He through the eternal Spirit, once offered up unto God, has fully satisfied the justice of His Father; and purchased not only reconciliation, but an everlasting inheritance in the kingdom of heaven, for those whom the Father has given unto Him. ${ }^{1}$

More recently, the Southern Baptist Convention passed a resolution reaffirming 'the truthfulness, efficacy, and beauty of the biblical doctrine of penal substitutionary atonement as the burning core of the Gospel message and the only hope of a fallen race'. ${ }^{2}$ This 'burning core of the

1 See also Chapter VIII, article V of the 1689 London Baptist Confession of Faith.

2 The Southern Baptist Convention, 'On the Necessity of Penal Substitutionary Atonement' (2017) TinyURL.com/TB70-Woz-2a (accessed 28 March 2019). 
Gospel' has even made its way into evangelical hymnody. P. P. Bliss's beloved hymn 'Hallelujah! What a Saviour' illustrates the centrality of penal substitutionary atonement for understanding the gospel when it declares,

\section{Bearing shame and scoffing rude In my place condemned he stood, Sealed my pardon with his blood Hallelujah! What a Saviour!}

Such worshipful declarations are meant to inspire greater love towards God for the tremendous sacrifice made on the cross by Christ. For some, however, such declarations do not inspire love. Rather, they generate revulsion towards a God who would sacrifice his innocent son, or, at the very least, they lead to disbelief that penal substitutionary atonement (PSA) is the best way to understand the good news of the gospel. Those who believe that PSA is not fitting of the good news revealed in the gospel have articulated a number of critiques of the view. ${ }^{3}$ These include subjective critiques (i.e., critiques concerning the problematic effects that the doctrine might have on individuals or society) and objective critiques (i.e., critiques concerning problematic elements of the doctrine itself).

One type of objective critique concerns the fittingness of speaking about God punishing Christ. This type of critique comes in two main forms. The first form of the critique - which dates back at least to Socinus and finds plenty of modern articulators - argues that PSA makes God out to be unjust. The second form of the critique, and perhaps the strongest critique of the doctrine, argues that it is not fitting to speak of God punishing Christ because the punishment of an innocent person is conceptually incoherent. Briefly stated, the incoherence objection goes as follows. 1) There are a number of necessary conditions for an act to count as a punishment. 2) Penal substitution is conceptually impossible given some of these necessary and sufficient conditions. 3) Therefore, it is incoherent to speak of Christ as a 'penal' substitute. In this essay I seek to defend the coherence of PSA by providing an account of Christ's relationship to humanity such that it is conceptually possible to meet the necessary and sufficient conditions for punishment. In order to do this, I

3 In her recent book The Crucifixion, Fleming Rutledge lists fourteen objections that have been levelled against the doctrine of penal substitution. Fleming Rutledge, The Crucifixion: Understanding the Death of Jesus Christ (Grand Rapids, MI: Eerdmans, 2015): 489-506. 
turn to Jonathan Edwards' metaphysics of creation and identity as resources for developing the metaphysics necessary for demonstrating that PSA is conceptually coherent.

This essay will proceed as follows. In the 'The Incoherence Objection' section, I articulate the incoherence objection and provide several ways advocates of PSA can respond to the objection. I then show how each of these responses, in one way or another, are found wanting. In the section following (3), I lay the groundwork necessary for developing the Edwardsean defence. In order to do this, I show how Edwards deals with the problem of the persistence of personal identity that arises from his doctrine of continuous creation. The result is a view I am calling 'Edwardsean Anti-Criterialism'. In the next section (4), I apply Edwardsean Anti-Criterialism to PSA in order to defend its coherence. ${ }^{4}$ I conclude by responding to four objections to the Edwardsean defence of PSA.

Before building my defence of the coherence of PSA, I ought to provide a caveat lector. First - despite the fact that I affirm PSA - this particular essay does not attempt to argue that PSA is the account of atonement that best makes sense of the scriptural witness to what God accomplished in Christ on the cross. Nor do I attempt to argue that PSA is or should be the pre-eminent model of atonement. Second, by the term 'Edwardsean' I hope to distinguish between Edwards' own defence of PSA and a defence inspired by Edwards' philosophical theology. By 'Edwardsean' I mean to indicate that this defence of the coherence of PSA is consistent with Edwards' reasoning, although it is not necessarily the defence Edwards himself would have provided. Finally, I do not attempt to argue that Edwardsean metaphysics actually is correct. Rather, I turn to Edwardsean metaphysics simply to show that it is possible to articulate a conceptually coherent account of PSA. Thus, the purpose of this essay is not to defend PSA as being true; rather, the scope of this essay is more limited - it is to defend the coherence of the doctrine.

4 For another treatment of Edwardsean Anti-Criterialism see Christopher Woznicki, " "Thus Saith the Lord": Edwardsean Anti-Criterialism and the Physicalist Problem of Resurrection Identity', Theologica 2 (2018): 1-21. 


\section{The Incoherence Objection}

What constitutes punishment? One standard definition of punishment delineates four elements as the necessary conditions for an act to count as a punishment. ${ }^{5}$ First, such an act must impose some sort of cost or hard treatment upon the person being punished. Obviously, this need not be monetary cost or physical hard treatment. What is necessary is that some form of hardship falls upon the recipient of the punishment. Second, the imposition of hard treatment must be intentional. That is, the hard treatment does not come about by accident; it is purposeful. Third, the hard treatment that is imposed must be in response to what is believed to be a wrongful act or omission. Finally, the hardship or loss must be imposed 'as a way of sending a message of condemnation or censure for what is believed to be a wrongful act or omission'. ${ }^{6}$ In recent years a number of philosophers have applied parts of definitions like the one provided above in order to critique PSA. The most well-known critique comes from Mark Murphy. ${ }^{7}$

In a recent essay, Murphy adopts a similar but modified list of necessary conditions for punishment.

P1: Punishment is hard treatment.

P2: Punishment is imposed by an authority who may legitimately impose hard treatment.

P3: Punishment is for a failure, i.e. one is subjected to punishment for failing to conform to some standard.

P4: Punishment expresses condemnation of the wrongdoer. ${ }^{8}$

Murphy focuses on $\mathrm{P} 4$, the expressivist condition, in order to critique PSA. In doing so, he adopts Joel Feinberg's expressivist understanding of punishment. In Feinberg's collection of essays, Doing and Deserving, he explains that the expressive function of punishment is a "conventional device for the expression of attitudes of resentment and indignation, and of judgments of disapproval and reprobation, on the part either of the punishing authority himself or of those "in whose name" the punishment

5 Alec Walen, 'Retributive Justice', The Stanford Encyclopedia of Philosophy (Winter 2016), ed. Edward Zalta TinyURL.com/TB70-Woz-5a (accessed 23 May 2019).

6 Walen, 'Retributive Justice'.

7 See also Brent Kyle, 'Punishing and Atoning: A New Critique of Penal Substitution', International Journal for Philosophy of Religion 74 (2013): 201-18.

8 Mark Murphy, 'Not Penal Substitution but Vicarious Punishment', Faith and Philosophy 26 (2009): 255-56. 
is inflicted' ${ }^{9}$ Hence, if something is going to be an act of punishment, it must have an expressive, condemnatory, function. ${ }^{10}$

At first glance this element of punishment seems problematic for the doctrine of penal substitution. This is especially true if PSA is explained as follows:

Sinners deserve to be punished for their sin. Christ undertakes the punishment for sin that sinners deserved. Because of this, sinners do not have to undertake that punishment themselves because God's justice is satisfied by the death of Christ.

Why is this explication of PSA especially problematic given the expressivist function of punishment? Well, it seems that this understanding of PSA is incoherent. Murphy argues that PSA is conceptually incoherent because 'punishment is expressive action, condemning the party punished, and so is not transferable from a guilty to an innocent party'. ${ }^{11}$ On this definition of PSA, one can say legitimately that PSA meets conditions P1, P2, and P3. However, it does not meet condition P4. This is because God cannot express condemnation, disapproval, or reprobation against Christ because Christ has not done anything wrong. Therefore, 'the classical penal substitution view of atonement view is incoherent'. ${ }^{12}$

\subsection{Potential Responses to the Incoherence Objection}

What should a believer in PSA do in light of Murphy's objection? Assuming that such a person does not want to abandon PSA, it seems that the PSA theorist has several options available.

First, the defender of PSA might deny the expressivist condition (P4). This might be reasonable given that number of philosophers of law omit the expressivist function of punishment in their definitions of punishment. Anthony Flew, Stanley Benn, and H. L. A. Hart are

9 Joel Feinberg, Doing and Deserving: Essays in the Theory of Responsibility (Princeton, NJ: Princeton University Press, 1970): 98.

10 See also Antony Duff and Zachary Hoskins, who state that in the standard accounts of punishment 'The central meaning and purpose of punishment ... is to communicate to offenders the censure or condemnation that they deserve for their crimes.' Antony Duff and Zachary Hoskins, 'Legal Punishment', The Stanford Encyclopedia of Philosophy (Fall 2018), ed. Edward Zalta TinyURL.com/TB70-Woz-10a (accessed 23 May 2019).

11 Murphy, 'Not Penal Substitution', 253.

12 Murphy, 'Not Penal Substitution', 260. 
prominent examples of this position. ${ }^{13}$ However, the expressivist function of punishment has become such a standard part of the legal definition of punishment that it is difficult to see how this aspect of punishment can be so easily dismissed. ${ }^{14}$

Second, the advocate of PSA might reinterpret what is meant by the expressivist condition. William Lane Craig offers this option as a possible way to defend PSA. ${ }^{15}$ According to Walen's account, the hardship imposed by the person punishing the offender acts 'as a way of sending a message of condemnation or censure for what is believed to be a wrongful act or omission' ${ }^{16}$ Craig notes that this explanation seems to leave some ambiguity as to what exactly is being censured: is the guilty party being censured or is the act itself being censured? Feinberg's definition of the expressivist function is also ambiguous. He states that the 'punishment expresses the community's strong disapproval of what the criminal did. Indeed, it can be said that punishment expresses the judgement of the community that what the criminal did was wrong. ${ }^{17}$ Again, what is the expressivist function directed towards - the criminal or the criminal's action? Based on this ambiguity, one might conclude that what is being censured when Christ dies on the cross are the sins of the world, and not Christ himself. Such a move seems to get around the incoherence objection. It is, however, still an unsatisfying solution. According to this revised understanding of the expressivist function, that which is being condemned or censured are the actions of the person receiving the hard treatment; yet, Christ has not committed any wrong actions. Strictly speaking, there are no actions for which Christ himself can be censured. The incoherence objection still lurks in the background.

A third way to get around the incoherence objection is to adopt an expressivist theory of punishment, the standard explication of PSA, plus a doctrine of imputation. Charles Hodge provides one standard account

13 Anthony Flew, 'The Justification of Punishment', Philosophy 29 (1954): 291-307; S. I. Benn, 'An Approach to the Problems of Punishment', Philosophy 33 (1958): 325-41; H. L. A. Hart, 'Prolegomenon to the Principles of Punishment', Proceedings of the Aristotelian Society 60 (1959/60): 1-26.

14 For critical discussions of the expressivist function see Michael Davis, Justice in the Shadow of Death: Rethinking Capital and Lesser Punishments (Lanham, MD: Rowman \& Littlefield, 1996): 169-81 and A. J. Skillen, 'How to Say Things with Walls', Philosophy 55 (1980): 509-23.

15 William Lane Craig, The Atonement (New York: Cambridge University Press, 2018): 60.

16 Walen, 'Retributive Justice'.

17 Feinberg, Doing and Deserving, 100. 
of imputation. He explains that 'to impute is to ascribe to, to reckon to, to lay to one's charge'. ${ }^{18}$ Imputation, Hodge clarifies, does not change the inward subjective state of the person to whom the imputation is made. For example, 'when sin is imputed to a man he is not made sinful ... when you impute goodness to a man, you do not make him good'. ${ }^{19}$ On this standard account, imputation is purely a forensic action. By adopting a standard account of the imputation of sin, like Hodge's, one can say that Christ is not personally guilty but is legally guilty, and therefore he can rightly be the target of moral censure. Craig explains:

On this view, although Christ did not himself commit the sins in question, God chose to treat Christ as if he had done those acts. Such language is formulaic for the expression of legal fictions. The nearly universal understanding of a legal fiction is something that the court consciously knows to be false but treats as if it were true for the sake of a particular action..$^{20}$

Critics of versions of PSA that rely on the doctrine of imputation are especially wary that atonement is a mere legal fiction. As a legal fiction, it seems as though salvation is either a mere pretence or that God knows the truth of the matter but chooses to act in such a way that is (legally) false. Craig offers two replies to these kinds of objections. To the first objection he states that "the claim is not that penal substitution is a fiction ... nor is his expiation of sin or propitiation of God's wrath a fiction ... All these things are real. What is fictitious is that Christ himself did the wrongful acts for which he was punished.' ${ }^{21}$ Thus, salvation is no mere pretence. To the second objection, Craig replies by arguing that legal fictions are not falsities; they are devices 'adopted precisely in order to bring about real and objective differences in the world'. ${ }^{22}$ As an example of a legal fiction, Craig asks us to consider how in legal cases a ship is considered a person. ${ }^{23}$ This legal fiction - the personhood of ships - was adopted because ship owners attempted to evade responsibility for violating maritime trade laws. When ships were seized, the captains would pass on legal responsibility to the ship owners, who in turn produced innocent manifests while denying any knowledge of illegal

18 Charles Hodge, Systematic Theology, Vol. 3: Soteriology (Peabody, MA: Hendrickson, 2011): 144.

19 Hodge, Systematic Theology, Vol.3, 145.

20 Craig, The Atonement, 61-62.

21 Craig, The Atonement, 62.

22 Craig, The Atonement, 62.

23 Craig, The Atonement, 63. 
activity of the captains and crews. American federal courts responded by making the ship itself the person against whom charges were brought. In turn, this legal fiction facilitated the condemnation and forfeiture of offending vessels and produced a more just and workable system of maritime law. ${ }^{24}$ This example of a legal fiction is supposed to show us how legal responsibility for acts can be imputed to other persons/objects who did not really do the actions, 'thereby producing real differences in the world outside of the fiction' ${ }^{25}$ In the case of PSA, the legal fiction that is enacted is that Christ himself is responsible for the deeds in question. Craig concludes his 'legal fiction' defence of imputation by stating that 'through the device of legal fictions we do, indeed, have some experience of how legal responsibility for acts can be imputed to another person who did not really do the actions' ${ }^{26}$ The result of this possibility is that Christ can be the object of moral censure or condemnation because the actions, legally speaking, are his. Thus, the doctrine of imputation provides a way to avoid the incoherence objection.

Although adopting the doctrine of imputation seems like a plausible way to get around the incoherence objection, the merely legal concept of imputation is not without problems. ${ }^{27}$ For example, the doctrine of imputation seems to ignore scriptures that indicate that atonement happens primarily because of our union with Christ, an ontologically real union and not merely a legal fiction. This concept is especially present Galatians 2:15-21 and Romans 6:1-14. ${ }^{28}$ According to both of these passages, atonement occurs when believers participate in Christ's death. They are crucified with Christ and in turn they are justified. ${ }^{29}$ If there is any doubt, the act of being crucified with Christ is not a mere metaphor, nor is it limited to the ethical. Rather, believers are said inhabit or indwell

24 Craig, The Atonement, 63.

25 Craig, The Atonement, 64.

26 Craig, The Atonement, 63-64.

27 Michael Horton presents a helpful overview of critiques and defences of the merely legal view of imputation in The Christian Faith: A Systematic Theology for Pilgrims on the Way (Grand Rapids, MI: Zondervan, 2011): 635-42.

28 Both passages employ the Greek verb systauroō, 'co-crucify'. Michael Gorman, Inhabiting the Cruciform God: Kenosis, Justification, and Theosis in Paul's Narrative Soteriology (Grand Rapids, MI: Eerdmans, 2009): 63.

29 Martinus de Boer, 'Paul's Use and Interpretation of a Justification Tradition in Galatians 2.15-2:21', JSNT 28 (2005): 214-15; Gorman, Inhabiting the Cruciform God, 67; Scott Schauf, 'Galatians 2:20 in Context', NTS 52 (2006): 101. 
in Christ. ${ }^{30}$ It is in virtue of this indwelling that believers are enabled to participate in Christ's death. Speaking specifically of the Romans passage, C. E. B. Cranfield explains that 'God willed to see them [believers] as having died in Christ's death and having been raised in his resurrection. ${ }^{31}$ God wills to see them this way because they are 'baptized into his death; through their baptism they were buried with him into death'. ${ }^{32}$

Imputation as a mere legal fiction does not take this concept of atonement in virtue of a metaphysically real union with Christ seriously enough. On such an account it seems as though imputation is possible without union. Scripture, however, does not indicate that Christ's death on our behalf was merely a legal fiction. Rather, scripture - especially Galatians 2:15-21 and Romans 6:1-14-seems to indicate that there is some metaphysical union between believers and Christ by which atonement is justly made. What does this union consist of? How can 'God will to see [believers] as having died in Christ's death'? ${ }^{33}$ Is there a way to get a doctrine of imputation that is not merely a legal fiction, but an ontological reality? Jonathan Edwards' theology of creation and philosophy of identity provide a way to do so.

\section{Jonathan Edwards' Metaphysics of Creation and Identity}

Traditionally, the doctrine of providence has been divided into two complementary categories: preservation and governance. Preservation concerns God's actions in regard to the continuation and continuing operation of the already established existence of the universe. ${ }^{34}$ Governance, on the other hand, concerns the way that God causes the universe to operate and, concerning its operations, to reach the goal intended by him. ${ }^{35}$ Edwards' views regarding governance are well known (he was a theological determinist) and are representative of his

30 Douglas Campbell, The Quest for Paul's Gospel: A Suggested Strategy (New York: T\&T Clark, 2005): 93.

31 C. E. B. Cranfield, 'Romans 6:1-14 Revisited', ET 106 (1994): 41.

32 Cranfield, 'Romans 6:1-14 Revisited', 41.

33 Cranfield, 'Romans 6:1-14 Revisited', 41.

34 Geerhardus Vos, Reformed Dogmatics, Vol. 1: Theology Proper, trans. Richard Gaffin Jr (Bellingham, WA: Lexham Press, 2014): 183.

35 Vos, Reformed Dogmatics, 183. 
Reformed heritage. ${ }^{36}$ His views regarding preservation, however, are less well known and perhaps more exotic. ${ }^{37}$ The development of Edwards' views on preservation arose, in part, due to his concern for the impact that certain deists were making in England and its colonies. In describing these theological opponents he labels them 'a new sect of infidels' ${ }^{38}$ This is because Edwards believed their views led to practices in which '[The] Bible is derided, Christ [is] openly blasphemed, and all doctrines and miracles ridiculed in public houses and open streets. ${ }^{39}$

Although there were several points of contention between Edwards and the deists, one major point of contention concerns what Edwards regards as a threat to God's sole aseity. God, according to Edwards, is the only being whose existence is in no way dependent, nor derived from anything, ad extra. Deists also claimed that God was a se; however, Paul Helm notes that they believed that divine power was mediated through the power given to created being, the result of which is that created beings had the power, in and of themselves, to sustain their existence after God's initial act of creation. ${ }^{40}$ For Edwards, this is unacceptable, because to his mind this robs God of his sole aseity. God is the sole ontologically independent being and the deist view gives created beings a form of ontological independence. Thus, Edwards says,

That God does, by his immediate power, uphold every created substance in being will be manifest, if we consider that their present existence is dependent existence, and therefore is an effect, and must have some cause: and the cause must be one of these two: either the antecedent existence of the same substance or else the power of the Creator. ${ }^{41}$

36 For discussions regarding how well Edwards fits into this tradition see Richard Muller, Divine Will and Human Choice: Freedom, Contingency, and Necessity in Early Modern Reformed Thought (Grand Rapids: Baker Academic, 2017): 324; Philip Fisk, Jonathan Edwards's Turn from the Classical-Reformed Tradition of Freedom of the Will (Göttingen: Vandenhoeck \& Ruprecht, 2016).

37 See Oliver Crisp, 'On the Orthodoxy of Jonathan Edwards', Scottish Journal of Theology 67 (2014): 304-22.

38 Jonathan Edwards, The Works of Jonathan Edwards Vol. 14: Sermons and Discourses 1723-1729, ed. Kenneth P. Minkema (New Haven, CT: Yale University Press, 1997): 498.

39 Edwards, The Works of Jonathan Edwards Vol. 14, 499.

40 Paul Helm, 'A Forensic Dilemma: John Lock and Jonathan Edwards on Personal Identity' in Jonathan Edwards: Philosophical Theologian, ed. Paul Helm and Oliver Crisp (Burlington, VT: Ashgate, 2003): 45.

41 Edwards, The Works of Jonathan Edwards Vol. 3: Original Sin, ed. Clyde Holbrook (New Haven, CT: Yale University Press, 1970): 400-401. Italics added. 
This quotation represents Edwards' problem with the deists well. On the one hand there are those who believe that the doctrine of preservation is best understood in terms of created substances continuing to exist as a function of their antecedent existence. On the other hand, there are those who believe that created substances continue to exist solely by the power of the Creator. Only the latter, Edwards believes, maintains the sole aseity of God. Walter Schultz explains that such a view entails that so long as any created substance exists, it exists only because God wills it. ${ }^{42}$ Furthermore, this entails that creation at the first moment of its existence is constituted by nothing more than God's existence-conferring acts of willing it to be. This implies that 'there is no difference between the first moment of a thing's existence and any subsequent moment of existence' ${ }^{43}$ The doctrines of creation ex nihilo and preservation are thereby collapsed, leading to a doctrine of continuous creation. Edwards himself states,

God's upholding created substance, or causing its existence in each successive moment, is altogether equivalent to an immediate production out of nothing, at each moment, because its existence at this moment is not merely in part from God, but wholly from him; and not in any part or degree, from its antecedent existence. ${ }^{44}$

Thus, the doctrine of continuous creation serves to 'underline the ongoing dependence of creation on the Creator as the only real being ... [expressing] that creation does not add anything to the Creator'. ${ }^{45}$ Additionally, this view helped Edwards as he 'dissociated himself from Deism' showing that '[God's] cosmos is continually sustained by him and his presence'. ${ }^{46}$

One potentially troublesome implication of Edwards' doctrine of continuous creation, ex nihilo, is that such a doctrine of creation implies that created beings do not persist through time. As Crisp and Strobel put it, 'Upon being created the world immediately ceases to exist because no

42 Oliver Crisp and Kyle Strobel suggest that part of the reason Edwards held to this view is that 'he was obsessed with preserving the absolute sovereignty of God'. Oliver Crisp and Kyle Strobel, Jonathan Edwards: An Introduction to His Thought (Grand Rapids, MI: Eerdmans, 2018): 109.

43 Walter Schultz, 'The Metaphysics of Jonathan Edwards's End of Creation', JETS 59 (2016): 357.

44 Jonathan Edwards, The Works of Jonathan Edwards Vol. 3: Original Sin, ed. Clyde Holbrook (New Haven, CT: Yale University Press, 1970): 402.

45 Willem Van Vlastuin, 'Creation' in The Jonathan Edwards Encyclopedia, ed. Harry

S. Stout (Grand Rapids, MI: Eerdmans, 2017): 122.

46 Van Vlastuin, 'Creation', 122. 
created thing has power in and of itself to continue to exist, and God does not conserve it in existence beyond its first moment of existence. ${ }^{47}$ This is not limited to non-personal created entities, but applies to persons as well. ${ }^{48}$ For example, Bob at time i $_{1}$ is not numerically identical with Bob at time ${ }_{2}$ because 'Bob' falls out of existence immediately after time ${ }_{1}$ and a new 'Bob' is created ex nihlo at time ${ }_{2}$, and so on. This seems problematic for various reasons. First, it seems to contradict our intuitions about personhood. It seems to us that when we interact with our friend Bob at 11:15am we are not interacting with a different person from the Bob we interacted with at 11:00am. Yet, Edwards' doctrine of continuous creation seems to demand that this is so. To such an objection Edwards says that 'the universe is created out of nothing every moment; and if it were not for our imaginations, which hinder us, we might see that wonderful work performed continually'. ${ }^{49}$ Edwards believes our ordinary experience does not lead us to see Bob in this way, but claims that the fact of it being counterintuitive does not make it false.

A second problematic element of such a view is that for moral responsibility to obtain we need to be able to say that a person at one point in time is the same person at another point in time. That is, if Bob is morally responsible for stealing a cookie from the cookie jar, the Bob who reaches his hand into the cookie jar at time ${ }_{1}$ and the Bob who takes the cookie from the cookie jar at time $e_{2}$ and the Bob who eats the cookie at time ${ }_{3}$ must be the same Bob. Otherwise, we are left asking, who took the cookie from the cookie jar? ${ }^{50}$ Who is supposed to be held morally responsible for the act of theft? Edwards overcomes this identity problem by appealing to divine fiat.

Edwards grounds the persistence of identity through time by arguing that God arranges the world in such a way that Bob is actually the aggregate of his various temporal and spatial parts. ${ }^{51}$ In Original Sin Edwards says,

47 Crisp and Strobel, Jonathan Edwards, 108.

48 S. Mark Hamilton argues otherwise - that minds endure across temporal stages. S. Mark Hamilton, A Treatise on Jonathan Edwards: Continuous Creation and Christology (Fort Worth: Jonathan Edwards Society Press, 2017): 36.

49 Jonathan Edwards, The Works of Jonathan Edwards Vol. 6: Scientific and Philosophical Writings, ed. Wallace E. Anderson (New Haven, CT: Yale University Press, 1980): 241-42.

50 Our intuitions tell us that Bob took the cookie from the cookie jar.

51 There is some discussion within Edwardsean studies as to whether Edwards' view amounts to perdurantism, exdurantism, or endurantism. Perdurance is the view that an individual is an aggregate of discrete temporal parts. Exdurance is the view that an 
Some things, existing in different times and places, are treated by their Creator as one in one respect, and others in another; some are united for this communication, and others for that; but all according to the sovereign pleasure of the Fountain of all being and operation. ${ }^{52}$

In other words, God regards Bob at time ${ }_{1}$ and $\mathrm{Bob}$ at time ${ }_{2}$ as one being, even though they are completely new creations. Edwards states 'identity of consciousness depends wholly on a law of nature; and so, on the sovereign will and agency of God; and therefore, that personal identity ... depends on an arbitrary divine constitution'. ${ }^{33}$ Thus, Bob at time ${ }_{1}$ and Bob at time ${ }_{2}$ are the same person simply by divine fiat. God regards them as one, therefore they are one. Edwards applies this understanding of identity towards explaining how God regards all of humanity as one with Adam, thus making them fit for the imputation of Adam's sin. Again, quoting Edwards's Original Sin,

I am persuaded, no solid reason can be given why God who constitutes all other created union or oneness, according to his pleasure ... may not establish a constitution whereby the natural posterity of Adam, proceeding from him ... should be treated as one with him, for the derivation either of righteousness and communion in rewards or the loss of righteousness and consequent corruption of guilt. ${ }^{54}$

According to this passage, union is constituted by God according to his own pleasure. His pleasure, or will, constitutes the relation between Adam and his posterity, which allows for corruption or guilt to be ascribed to Adam's descendants. This is just one example of how Edwards applies his understanding of identity to his theological reasoning.

\subsection{Edwardsean Anti-Criterialism}

Until now we have claimed that for Edwards an object's persistence of identity over time is a matter of divine fiat. Despite the fact that each object is created ex nihilo in one moment, falls out of existence the next, and a new qualitatively identical object is created ex nihilo in the

individual is an aggregate of numerous stages. Endurance is the view that a thing persists through time if and only if it exists wholly at different times. See Oliver Crisp, Jonathan Edwards on God and Creation (New York: Oxford, 2012): 14-36; Hamilton, A Treatise on Jonathan Edwards; Woznicki, 'Thus Saith the Lord', 1-21. For the purposes of this paper, it does not matter much whether persons are composed of parts or stages.

52 Edwards, The Works of Jonathan Edwards Vol. 3, 405.

53 Edwards, The Works of Jonathan Edwards Vol. 3, 399. Italics added for emphasis.

54 Edwards, The Works of Jonathan Edwards Vol. 3, 405. 
subsequent moment, Edwards can say that such an object is in fact the same object only because God has sovereignly declared that it is so. Such a view amounts to a form of anti-criterialism. This is the view that there are no metaphysically informative criteria for describing the persistence of identity of an object. What are metaphysically informative criteria? According to Trenton Merricks, criteria for personal identity are informative only 'if one can, at least in principle, assert that they are satisfied without presupposing the identity for which they are said to be criteria'. ${ }^{55} \mathrm{He}$ argues that there are no such criteria. His argument against criterialism - the view that there are informative conditions for identity - amounts to showing that any possible criterion for personal identity over time results in a tautological proposition. Because such identity statements are tautological, they are not informative, and hence cannot truly be identity criteria. It seems that Edwards' divine fiat account of the persistence of identity is not informative in the sense that Merricks describes. However, just because there are no criteria of identity does not mean that there are no informative sufficient conditions for identity. Merricks believes that there can be metaphysically sufficient explanations of identity, even if these explanations are not informative in the metaphysically robust sense he describes. As an example of a metaphysically sufficient explanation of identity that is not informative he provides an example using the concepts of laws of nature and biological processes. He explains, "it is consistent with the rejection of criterialism that an informative and metaphysically sufficient condition for $\mathrm{P}$ at $t$ to be identical with $\mathrm{P}^{*}$ at $t^{*}$ is that laws of nature $\mathrm{L}$ hold at $\mathrm{P}$ at $t$ is related to $\mathrm{P}^{*}$ at $t^{*}$ by biological process $\mathrm{B}^{3} .{ }^{56} \mathrm{We}$ can adopt the form of Merricks' articulation of anti-criterialism and give it a more Edwardsean flavour. The result is the following:

Edwardsean Anti-Criterialism (EAC): The metaphysically sufficient condition that an object, $\mathrm{O}$, at $t$ being identical with another object, $\mathrm{O}^{*}$, at $t^{*}$ is that God declares that Bob at $\mathrm{t}$ is related to Bob* at $t^{*}$ by divine fiat.

Such an anti-criterialist view is consistent with Edwards' account of persistence of identity over time. But how does EAC help solve to

55 Trenton Merricks, 'How to Live Forever without Saving Your Soul: Physicalism and Immortality' in Soul, Body, and Survival: Essays on the Metaphysics of Human Persons, ed. Kevin Corcoran (Ithaca, NY: Cornell University Press, 2001): 185.

56 Merricks, 'How to Live Forever', 195-96. 
incoherence objection levelled at PSA? To this we now turn our attention.

\section{An Edwardsean Account of Penal Substitution}

We noted above that, according to the standard account, imputation means to ascribe, reckon, or to lay to one's charge a particular action to someone that is not particularly their own. This is a forensic act. William Lane Craig has argued that imputation allows the defender of PSA to avoid charges of incoherence; however, we also noted that if imputation is to be used to defend PSA what is needed is an account of imputation that is based upon union with Christ. I suggest the following account of PSA, which relies upon imputation and union with Christ, as one way to defend the coherence of this doctrine. Let us call this account Edwardsean Penal Substitution (EPS).

The view is this. Humanity has sinned by violating God's law. As a result, sinners have merited punishment from God. The punishment for $\sin$ is death. Until God's justice is satisfied there is an obstacle to a proper relationship with God. In order to reconcile us to himself, God decided to make atonement for the sins of humanity. Step one, God becomes incarnate as a human being in Jesus Christ. Step two, Christ recapitulates the life of humanity as it was intended to be lived, thereby fulfilling all righteousness. Step three, Christ dies the death that human beings deserved as a punishment for sin, thereby satisfying God's justice. His death on the cross counts for sinners because their sinful actions are imputed to Christ. Specifically, they are imputed to Christ according to the criteria described in EAC. Step four, Christ is resurrected.

What does it mean to say that sinners' sinful actions are imputed to Christ according to EAC? I suggest the following. The incarnate Christ is a four-dimensional entity that is made up of a number of temporal parts ${ }^{57}$ Christ has the parts: Christ 1 at Time $_{1}$, Christ $_{2}$ at Time $_{2}$, Christ $_{3}$ at Time $_{3} \ldots$ Christ $_{n}$ at Time $n$. These temporal parts are all the same person in virtue of divine fiat; furthermore, each of Christ's parts commit actions that are morally praiseworthy. So far, this is nothing but EAC as

57 Four-dimensionalism is the view that objects have spatial and temporal parts. This can be contrasted with endurantism, which is the view that objects only have spatial parts. The 'four' in four-dimensionalism refers to time. See Katherine Hawley, 'Temporal Parts', The Stanford Encyclopedia of Philosophy (Spring 2018), ed. Edward Zalta TinyURL.com/TB70-Woz-57a (accessed 23 May 2019). 
applied to personal identity. Now consider another person, for example Jane. Jane has the parts Jane ${ }_{1}$ at Time 1 , Jane 2 at Time 2 , Jane ${ }_{3}$ at Time $e_{3} .$. Jane $_{\mathrm{n}}$ at Timen. These temporal parts constitute one person by virtue of divine fiat. Again, this is just EAC. Now consider that parts of Jane, $\mathrm{Jane}_{1}$ and Jane $\mathrm{J}_{3}$, commit morally blameworthy actions, i.e., sins. But Jane's part, Jane 2 , commits a morally praiseworthy action. I suggest that instead of the standard account of imputation, which forensically imputes Jane's morally blameworthy actions at Jane ${ }_{1}$ and Jane ${ }_{3}$ to Christ as a legal fiction, what actually happens is that by divine fiat Jane's parts, Jane $_{1}$ and Jane ${ }_{3}$, become a part of Christ. Thus, when Christ dies on the cross, fulfilling divine justice, God sees Christ as being constituted by the parts Christ ${ }_{1}$, Christ $_{2}$, Christ $_{3} \ldots$ Christ $_{n}+$ Jane $_{1}$, Jane $_{3}$. This happens in virtue of God's sovereign declaration that all these parts constitute Christ. The result is twofold. First, those parts in which morally blameworthy actions were committed by Jane are put to death with Christ on the cross. They are co-crucified with Christ in virtue of God's declarative act of union. Because Jane's parts in which morally blameworthy actions were put to death with Christ, she is absolved of needing to pay the penalty for sin. When God sees Jane, God sees that Jane has parts that have been crucified with Christ. Thus Jane (as a whole) no longer needs to pay the penalty for her sins. Second, parts that committed morally blameworthy actions have been united to Christ, so Christ in virtue of having these parts is now the kind of object which is fit for condemnation or the moral censure necessary for punishment to obtain. Christ can fulfil the expressivist condition. This second consequence of EPS allows us to avoid the incoherence objection while maintaining that imputation is more than forensic: it is ontologically real.

\section{Objections to Edwardsean Penal Substitution}

A number of objections can be levelled against EPS. Let us now take them in turn. The first objection that can be made against EPS is that it still relies on a divine fiction. Recall, one objection that some have made against the standard account of imputation is that it is a mere fiction. If the standard account of imputation relied on a fiction about how actions are reckoned to those who have not committed them, EPS seems to be grounded in a fiction about the four-dimensional parts of persons. In EPS it seems as though the fiction is that Jane ${ }_{1}$ is a part of Christ simply 
because God treats Jane ${ }_{1}$ as a part of Christ. But just because one treats one thing as a part of another or because one decides to act as though one thing is part of another does that make it the case that it is in fact a part of the other object. Treating one thing 'as if it were another' typically does not constitute new ontological realities. As the saying goes, a rose by any other name is still a rose. Calling a rose a tulip does not make it a tulip. Treating the rose as a tulip would be an act of fiction. Consider another example. Imagine I have a housecat named Simba. Let us say I treat Simba as a lion. Such an action does not make it the case that Simba is in fact a lion. Is God's declaration that Christ is constituted by Christ 1, Christ $_{2}$, Christ $_{3} \ldots$ Christ $_{n}+$ Jane $_{1}$, Jane 3 instead of just Christ $\mathrm{Christ}_{2}, \mathrm{Christ}_{3} \ldots$ Christ $_{n}$ a fictional declaration, like calling a rose a tulip or a housecat a lion, or is it an ontological reality? Those who argue that EPS relies on a fictional declaration misunderstand the nature of EAC. Recall that EAC, a version of anti-criterialism, states that the metaphysically sufficient condition that $\mathrm{O}$ at $t$ being identical with $\mathrm{O}^{*}$ at $t^{*}$ is that the divine declaration makes it true that $\mathrm{O}$ at $t$ is identical to $\mathrm{O}^{*}$ at $t^{*}$. Because anti-criterialism, in this case, is assumed to be true, there are no informative conditions for why Christ ${ }_{1}, \mathrm{Christ}_{2}, \mathrm{Christ}_{3} \ldots \mathrm{Christ}_{\mathrm{n}}$ are all parts of Christ. This set of temporal parts are the parts of Christ simply in virtue of a divine declaration. If one is willing to grant this claim then there is no reason to deny that the Christ $_{1}, \mathrm{Christ}_{2}, \mathrm{Christ}_{3} \ldots \mathrm{Christ}_{\mathrm{n}}+$ Jane $_{1}$, Jane $_{3}$ are also parts of Christ in virtue of divine declaration. Further, if one is willing to grant that God's declaration that Christ, Christ $_{2}, \mathrm{Christ}_{3} \ldots$ Christ $_{\mathrm{n}}$ are all parts of Christ is not a fiction, then one should be willing to grant that God's declaration that Christ ${ }_{1}$, Christ $_{2}$, Christ $_{3} \ldots$ Christ $_{n}+$ Jane $_{1}$, Jane 3 are all parts of Christ is also not a fiction. The only way that Christ being constituted by Christ ${ }_{1}, \mathrm{Christ}_{2}, \mathrm{Christ}_{3} \ldots$ Christ $_{n}+$ Jane $_{1}$, Jane $_{3}$ would be a fiction is if there were some criteria which would allow for $\mathrm{Christ}_{1}, \mathrm{Christ}_{2}$, Christ $\mathrm{C}_{3}$ to be parts of Christ and would exclude Christ ${ }_{1}$, Christ $_{2}$, Christ $_{3} \ldots$ Christ $_{n}+$ Jane $_{1}$, Jane $_{3}$ from being parts of Christ. So, the divine fiction objection does not hold.

A second objection that could be brought up against EPS is that it is arbitrary. After all, couldn't God just gerrymander some object that includes a gummy bear, a television, and a Starbucks cup and just declare it to be one object? Or couldn't God constitute a person that includes the parts $\mathrm{K}_{8}$ of Kobe Bryant, $\mathrm{L}_{23}$ of Lebron James, and $\mathrm{W}_{99}$ of Wayne Gretzky? If so, then isn't also arbitrary that God would declare the crucified Christ as being constituted by Christ ${ }_{1}, \mathrm{Christ}_{2}, \mathrm{Christ}_{3} \ldots$ Christ $_{n}$ 
+ Jane $_{1}$, Jane $_{3}$ ? Strictly speaking, God could gerrymander a gummy bear, a television, and a Starbucks cup as one object, or the parts $\mathrm{K}_{8}$ of Kobe Bryant, $\mathrm{L}_{23}$ of Lebron James, and $\mathrm{W}_{99}$ of Wayne Gretzky as one person. Edwards, however, would say that God in his wisdom would not do such a thing. Yes, Edwards believed that identity is by divine fiat, but that is not all there is to identity declarations. Edwards believed that there is a certain fittingness as to what God would regard as one by divine fiat. Paul Helm explains that, for Edwards, God 'makes truth not whimsically or in a random fashion, but in accordance with his own wise purposes'. ${ }^{58}$ Oliver Crisp says that "this notion of being "made one" that Edwards uses is not mere conventionalism'. ${ }^{59}$ Yes, constitution depends on nothing but the divine will, but 'divine will depends on nothing but the divine wisdom'. ${ }^{60}$ Thus, if there is some wise reason for declaring Christ $_{1}$, Christ $_{2}$, Christ $_{3} \ldots$ Christ $_{n}+$ Jane $_{1}$, Jane 3 to be one person, then it would not be an arbitrary declaration. What might be grounds for calling this declaration wise? Perhaps it would be a wise action if there were something that made this declaration reasonable. That two entities are of the same natural kind might, for example, provide a wise reason for making such a declaration. ${ }^{61}$ If that is the case, then God declaring that the parts of one human and the parts of another human constitute the identity of one person might be a wise declaration.

Another wise reason for this declaration might be that the 'larger' entity into which the parts of another entity are grafted into stands in a representative relation to the other entities. This might be fulfilled if Christ were the federal head of humanity. As the federal head of humankind, it would be reasonable for God to declare that parts of other human beings constitute parts of the larger whole of Christ crucified. Edwards in fact did believe that Christ was 'our second federal head'. ${ }^{62}$ As our federal head, Edwards reasons,

58 Helm, 'A Forensic Dilemma', 56.

59 Oliver Crisp, Jonathan Edwards and the Metaphysics of Sin (Burlington, VT: Ashgate, 2005): 101.

60 Edwards, The Works of Jonathan Edwards Vol. 3, 403.

61 An objection that might be raised is that two objects are a 'natural kind' by divine fiat as well, thus making the position circular. This, under an Edwardsean scheme, need not be so. Edwards' thought is consistent with divine conceptualism, the view that concepts exist in God's mind. Thus, God could have an archetypal concept of a tiger, tulip, or human in his mind.

62 Jonathan Edwards, The Works of Jonathan Edwards Vol. 19: Sermons and Discourses 1734-1738, ed. M. X. Lesser (New Haven, CT: Yale University Press, 2001): 187. 
[Christ] acted the part for us, that the first Adam should have done: when he had undertaken to stand in our stead, he was looked upon, and treated as though he were guilty with our guilt; and by his satisfying, or bearing the penalty, he did as it were free himself from this guilt. ${ }^{63}$

If this line of reasoning, which states that Christ is related to us as our federal head, is correct then it seems as though the declaration Christ ${ }_{1}$, Christ $_{2}$, Christ $_{3} \ldots$ Christ $_{n}+$ Jane $_{1}$, Jane $_{3}$ are one object is not arbitrary.

A third objection that could be brought up against EPS is that the doctrine of continuous creation is counterintuitive and therefore makes EPS less plausible. A few responses could be given to this objection. First, as we noted above, Edwards claimed that 'if it were not for our imaginations, which hinder us, we might see that wonderful work performed continually'. ${ }^{64}$ So according to Edwards it is only counterintuitive because our imaginations hinder us from seeing God's continuous work of creation. Second, we might point out that just because a claim is counterintuitive that does not make it false. Even if it is false, our purpose in this essay was not to provide a true account of PSA that avoids the incoherence objection; rather, it was to provide a coherent account of PSA. Finally, we can respond to this objection by pointing out that there is nothing in EAC that demands that one hold to the doctrine of continuous creation. Edwards' own account of identity includes belief in continuous creation, but Edwardsean Anti-Criterialism does not. Like the previous two objections, this third objection also misses the mark.

The fourth objection that can be raised against EPS is that it has the unacceptable consequence of making Christ sinful. Under the standard account of imputation the inward, subjective state of the person to whom imputation is made does not change. ${ }^{65}$ 'When sin is imputed to a man he is not made sinful.' ${ }^{66}$ Christ, to whom our are sins are imputed, is not made to be sinful; rather, he is treated as though he were sinful. Edwards himself says that the sin that Christ was punished for was not 'sin that he himself committed, but that sin that was laid upon him, or that he took upon him' ${ }^{67}$ Under EPS, however, the declaration of imputation is no

63 Edwards, The Works of Jonathan Edwards Vol. 19, 187.

64 Edwards, The Works of Jonathan Edwards Vol. 6, 241-42.

65 Hodge, Systematic Theology, Vol. 3, 144.

66 Hodge, Systematic Theology, Vol. 3, 144.

67 Jonathan Edwards, The Works of Jonathan Edwards Vol. 20: 'The Miscellanies', 833-1152, ed. Amy Plantinga Pauw (New Haven, CT: Yale University Press, 2002): $375-76$. 
mere fiction. The parts of other human beings who committed sinful actions are declared to be part of Christ. Recall, Jane's parts Jane ${ }_{1}$ and $\mathrm{Jane}_{3}$ are parts in which morally blameworthy actions were committed. These parts are declared by God to be parts of Christ. Thus, it could be said that the person of Christ really contains parts that are guilty of sin, making Christ sinful. This is a significant objection to EPS. However, it is not insurmountable if we make an important distinction. We can distinguish between those parts of Christ which are distinctively his and those that are his only in virtue of being imputed to him. The first category of parts, those which are distinctively his, are still his parts only in virtue of divine fiat. The reason that the parts Christ ${ }_{1}, \mathrm{Christ}_{2}, \mathrm{Christ}_{3}$ ... Christ ${ }_{n}$ constitute Christ is simply because God has deemed it so. However, we can say that these parts are distinctively his because they bear a certain relation to one another that other parts, like Jane ${ }_{1}$ and Jane ${ }_{3}$, do not bear. What is this relation? Perhaps it is that the sequential parts share something like physical proximity. One might posit any number of properties that only parts $\mathrm{Christ}_{1}, \mathrm{Christ}_{2}, \mathrm{Christ}_{3}$ share. Let us call such a property $\mathrm{P}$. It is the fact that a particular part has property $\mathrm{P}$ that makes those parts distinctively Christ's. The second category of Christ's parts are those that are only his in virtue of imputation. These parts do not have the property $\mathrm{P}$ and thus they are not distinctively his. Employing this distinction, we can say that all the parts that are distinctively his are all morally praiseworthy and hence righteous and that the parts which are Christ's only in virtue of imputation are morally blameworthy and hence sinful. In turn we can say that Christ, properly speaking, is sinless because no sins were committed by any of his distinctive parts. But Christ as he is crucified has parts, though not distinctively his, which are sinful. They are only his in virtue of the union declared by God. Such a view is consistent with 2 Corinthians 5:21, which states that 'For our sake he made him to be sin who knew no sin, so that in him we might become the righteousness of God' (NRSV). Following this line of thought we can say along with Edwards that the sin that Christ was punished for was not 'sin that he himself committed' (sin that was distinctively his) but sin that 'he took upon him' ( $\sin$ in virtue of imputation). ${ }^{68}$ This is one way to avoid the objection regarding Christ's sinfulness. And thus, four major objections to EPS have been addressed.

68 Edwards, The Works of Jonathan Edwards Vol. 20, 375-76. 


\section{Conclusion}

Jonathan Edwards once wrote that 'the importance of all Christian doctrines whatsoever, will naturally be denied in consequence of denying that one great doctrine of the necessity of Christ's satisfaction to divine justice ... This is as it were the center and hinge of all doctrines of pure revelation. ${ }^{69}$ For Edwards, like many of his fellow Reformed believers and many of the evangelicals who would later look to him as an exemplar of evangelical piety, PSA was a doctrine of utmost importance. In this essay I have shown that this doctrine, contra the claim of its opponents, need not be incoherent. I have shown this by providing a version of PSA which we have called Edwardsean Penal Substitution. This version of PSA provides a coherent way of understanding what it might mean to say that Christ was punished on behalf of sinners. Hopefully, upon seeing that this doctrine is coherent, believers in PSA can continue to confidently sing

In Christ alone, Who took on flesh,

Fullness of God in helpless babe!

This gift of love and righteousness,

Scorned by the ones He came to save.

'Til on that cross as Jesus died,

The wrath of God was satisfied

For ev'ry sin on Him was laid

Here in the death of Christ I live.

There in the ground His body lay, Light of the world by darkness slain

Then bursting forth in glorious day,

Up from the grave He rose again!

And as He stands in victory,

Sin's curse has lost its grip on me

For I am His and He is mine

Bought with the precious blood of Christ. ${ }^{70}$

69 Jonathan Edwards, The Works of Jonathan Edwards Online Vol. 27: 'Controversies' Notebook, ed. Jonathan Edwards Center (New Haven, CT: Yale University Press, 2008). 70 Stuart Townend and Keith Getty, 'In Christ Alone My Hope is Found (In Christ Alone)', 2001. I would like to thank James Arcadi, J. T. Turner, and the anonymous reviewers for helpful comments on this essay. 